\title{
The European Blood Directive (Directive 2002/98/EC) in the Context of the European Community Legislation
}

\author{
Susanne List ${ }^{\mathrm{a}, \mathrm{b}} \quad$ Mariam Klouche $^{\mathrm{a}}$ \\ a Bremer Zentrum für Laboratoriumsmedizin, Bremen, \\ ${ }^{b}$ Forschungsstelle für Medizinrecht, Fachbereich Rechtswissenschaft, Universität Regensburg, Germany
}

\author{
Key Words \\ European Blood Directive · Directive 2002/98/EC . \\ Community legislation · Blood transfusion - Safety
}

\section{Summary}

The European Blood Directive and its implementing Commission Directives fill a regulatory gap by providing the first detailed authoritative European Community legislation to set uniform minimum standards for blood transfusion safety in the European Community. This review will summarize the structure and novelties of the European Directive and focus on the legal balance of national and European law regarding the implementation in the face of the European subsidiarity principle. The European Blood Directives determine several new functions and definitions, including the responsibilities and qualification of the personnel, requirements regarding designation, authorization, accreditation and licensing of blood establishments as well as the establishment of concrete measures for quality management, and introduce for the first time mandatory multinational hemovigilance. By setting more detailed standards for the provision of quality and safety of blood and blood components with particular focus on the prevention of the transmission of viruses, bacteria and parasites, as well as on demands regarding data protection and confidentiality, the directive goes beyond most preexisting national standards. However, several aspects of transmissible pathogen testing or exclusion requirements lack concrete execution requirements. The level of homogeneity with in Europe will depend on the level of conformity of the countries with the European guidelines, but also on the respective national decisions to exceed the European standards, thus potentially complicating the interchangeability of blood products and the attempted European self-sufficiency. Continuous implementing activities in the member states demonstrate that the European Blood Directive already is on the road to success.

\author{
Schlüsselwörter \\ Europäische Blutrichtlinie · Richtlinie 2002/98/EG . \\ Gemeinschaftsgesetzgebung · Bluttransfusion · Sicherheit
}

\section{Zusammenfassung}

Die Europäische Blutrichtlinie mit den Durchführungsrichtlinien der Europäischen Kommission legen erstmals einheitliche verbindliche Mindeststandards für die Sicherheit von Bluttransfusionen in der Europäischen Gemeinschaft fest. Neben der Zusammenfassung der Struktur und wichtigsten Neuerungen, stellt die Erörterung der Balance zwischen nationalem und europäischem Recht in der Umsetzung der Richtlinie unter Maßgabe des Subsidiaritätsprinzips einen Schwerpunkt dieses Übersichtsartikels dar. Die Europäischen Blutrichtlinien legen einheitliche Definitionen für Begriffe der Transfusionsmedizin fest und bestimmen einheitliche Anforderungen für die Benennung, Herstellungserlaubnis, Zulassung oder Anerkennung von Blutspendeeinrichtungen, einschließlich Inspektionen und Kontrollmaßnahmen. Die Richtlinien legen Verantwortlichkeiten und Qualifikation des Personals, ein Qualitätsmanagementsystem sowie erstmals verbindliche multinationale Richtlinien und Definitionen für die Hämovigilanz fest. Durch die Definition detaillierter Standards für die Qualität und Sicherheit von Blut und Blutbestandteilen, welche speziell die Prävention der Übertragung von Viren, Bakterien und Parasiten betreffen und die Anforderungen an Datenschutz und Vertraulichkeit, geht die Direktive über bestehende nationale Standards hinaus. Die Einheitlichkeit der Qualität von Blutprodukten in Europa wird einerseits von der Richtlinienkonformität, andererseits davon abhängen, inwieweit die jeweiligen nationalen Regelungen und Gesetzte über die Europäische Direktive hinausgehen und somit einen freien Austausch von Blutprodukten und die angestrebte Selbstversorgung innerhalb Europas erschweren können. Die Implementierungsaktivitäten in den Mitgliedstaaten zeigen jedoch, dass die Europäische Blutrichtlinie bereits auf einem erfolgreichen Weg ist.

\begin{tabular}{ll}
\hline KARGER & ( ) 2006 S. Karger GmbH, Freiburg \\
Fax +497614520714 & Accessible online at: \\
$\begin{array}{l}\text { E-mail Information@Karger.de } \\
\text { www.karger.com }\end{array}$ & www.karger.com/tmh
\end{tabular}




\section{Introduction}

The European Parliament and the Council of Europe have issued directives to redefine the standards for the quality and safety of human blood and blood products that are mandatory in countries of the European Community. They emphasize the public need to i) strengthen the confidence in transfusion safety by providing uniform chains within Europe, and ii) to promote European self-sufficiency to guarantee transfusion supply autonomy. This aim has now concluded in the setting of standards for collection, testing, processing, storage and distribution of human blood. Since its existence, the Directive 2002/98/EC of the European Parliament and the Council of Europe of 27th January 2003, published in the Official Journal of the European Union (EU) L 33, p. 30 on 8th February 2003, has been known as the 'European Blood Directive' [1]. The objective of the European Blood Directive is to appoint uniform standards of quality and safety of human blood and blood components by defining minimum criteria in order to ensure a high level of human health protection throughout Europe (Article 1 Directive 2002/98/EC). In accordance with the Directive 2002/98/EC, this comprises the contribution to general confidence both in the quality of donated blood and blood components and in the health protection of donors, the attainment of self-sufficiency at a Community level and the enhancement of confidence in the safety of the transfusion chain among the member states. Commenting on the 2 implementing Commission Directives issued last year, Markos Kyprianou, the EU health commissioner, said: 'Healthcare staff and patients need to be confident the blood they are using is safe. Having common safety standards and safety systems across the EU helps facilitate cooperation between healthcare systems by enabling them to import blood from each other. It also helps give Europeans confidence that wherever they receive treatment in Europe, they will be properly protected from blood-transmissible diseases.' [2].

It is the subject of this article to present the legislative structure in which the European Blood Directive is situated, to summarize its content and to demonstrate how its conception guarantees the Directive's success, putting it in a position to realize the objective of harmonization and blood safety levels described by the EU Health Commissioner for the European Community.

\section{Legislative Structure Provided by the European Community}

Within the European Community, the principles of subsidiarity and proportionality are the 2 mainstays of Community legislative intervention (Article 5 of the Treaty Establishing the European Community - EC Treaty). The principle of subsidiarity implies that in areas which are not in its exclusive competence, the Community takes action only if and in so far as the objectives of the proposed action cannot be sufficiently achieved by the member states and can be better achieved by the Community. The principle of proportionality regulates that any Community action to fulfil this demand shall not go beyond what is necessary to achieve a high level of health protection.

The objectives of the European Blood Directive - i) to contribute to general confidence both in the quality of donated blood and blood components and in the health protection of the donors, ii) to attain self-sufficiency at a Community level and iii) to enhance confidence in the safety of the transfusion chain among the member states - cannot be sufficiently achieved by the member states alone. By reasons of their scale and effects, the Community objectives can therefore be better achieved at a Community level so that for the European Blood Directive the subsidiary competence according to the EC Treaty was given.

According to this competence, the European Parliament has issued the European Blood Directive in order to attain a uniformly high level of health protection in all member states in transfusion of blood products, acting jointly with the European Council and the European Commission. The Directive is - like every other EU directive - mandatory for each member state regarding the results to be achieved, but leaves to the national authorities the choice of form and methods (Article 249 of the EC Treaty). What is of note is that the Directive's provisions cannot affect national provisions on the donations of blood (Article 152 (2) EC Treaty). Besides, the member states may of course maintain or introduce more stringent protective measures relating to the standards of quality and safety of blood and blood components (Article 152 (4) EC Treaty).

Before the issuing of the Directive 2002/98/EC, measures to ascertain quality and safety of whole blood, plasma and blood cells for transfusion were not subject to any authoritative Community legislation. This regulative lack owed to the fact that the quality, safety and efficacy requirements of proprietary industrially prepared medicinal products derived from human blood or plasma were addressed in Directive 2001/83/EC [3]. However, this Directive explicitly excluded its application to whole blood, plasma and blood cells of human origin. The need for a uniform European Community blood safety strategy including blood and blood components irrespective of their intended purpose was already identified in the Commission's communication of 21st December 1994 on Blood Safety and Self-sufficiency in the EU. Consecutively, Council resolutions of 2nd June 1995 on blood safety and selfsufficiency in the Community [4] and of 12th November 1996 on a strategy towards blood safety and self-sufficiency in the European Community [5] and resolutions of the European Parliament of 14th September 1993 [6], 18th November 1993 [7], 14th July 1995 [8] and 17th April 1996 [9] were issued and lead to the proposal of the Commission [10]. This proposal as well as the opinion of the Scientific Committee for Medicinal 


\begin{tabular}{|c|c|c|}
\hline \multicolumn{3}{|c|}{$\begin{array}{c}\text { Directive 2002/98/EC } \\
\text { Mother directive' } \\
\text { Transposition not later than 8th February } 2005 \text { (Article } 32 \text { (1) Directive 2002/98/EC) }\end{array}$} \\
\hline \multicolumn{3}{|c|}{ As far as } \\
\hline $\begin{array}{l}\text { Provision of information to prospective } \\
\text { donors (Articles 16, } 29(\mathrm{~b}) \text { ), } \\
\text { Information required from donors } \\
\text { (Articles } 17,29(\mathrm{c}) \text { ), } \\
\text { Eligibility of donors (Articles } 18,29(\mathrm{~d}) \text { ), } \\
\text { Storage, transport and distribution } \\
\text { conditions (Articles } 22,29(\mathrm{e}) \text { ), } \\
\text { Quality and safety requirements for blood } \\
\text { and blood components (Articles } 23,29(\mathrm{f}) \text { ), } \\
\text { Requirements applicable to autologous } \\
\text { transfusions (Article } 29(\mathrm{~g}) \text { ) }\end{array}$ & $\begin{array}{l}\text { Traceability (Articles 14, } 29(\mathrm{a}) \text { ), } \\
\text { Notification of serious adverse events and } \\
\text { reactions (Articles } 15,29 \text { (i)) }\end{array}$ & $\begin{array}{l}\text { Quality system for blood establishments } \\
\text { (Articles } 11(2), 29(\mathrm{~h}))\end{array}$ \\
\hline \multicolumn{3}{|c|}{$\begin{array}{l}\text { are concerned: } \\
\text { Procedure referred to in Article } 28 \text { (2) Directive 2002/98/EC is applied }\end{array}$} \\
\hline \multicolumn{3}{|c|}{$\begin{array}{l}\text { Regulatory procedure: Commission assisted by a regulatory committee composed of the representatives of the member states and } \\
\text { chaired by the representative of the Commission, involving the Council and the European Parliament, publication in the Official } \\
\text { Journal of the European Communities (Articles 5, 7,8 of Decision 1999/468/EC) }\end{array}$} \\
\hline \multicolumn{3}{|c|}{ this results in: } \\
\hline $\begin{array}{l}\text { Commission Directive 2004/33/EC } \\
\text { Transposition not later than 8th February } \\
2005 \\
\text { (Article } 9 \text { (1) of Directive 2004/33/EC), } \\
\text { without prejudice of the transitional } \\
\text { period for blood establishments of } 9 \\
\text { months of Article } 7 \text { of Directive } \\
\text { 2002/98/EC (Article } 9 \text { (1) of Directive } \\
2004 / 33 / E C)\end{array}$ & $\begin{array}{l}\text { Commission Directive 2005/61/EC } \\
\text { Transposition not later than 31st August } \\
2006 \\
\text { (Article } 10 \text { (1) of Directive 2005/61/EC), } \\
\text { without prejudice of the transitional } \\
\text { period of } 9 \text { months of Article } 7 \text { of } \\
\text { Directive } 2002 / 98 / \mathrm{EC} \text { (Article } 10 \text { (1) of } \\
\text { Directive 2005/61/EC) }\end{array}$ & $\begin{array}{l}\text { Commission Directive 2005/62/EC } \\
\text { Transposition not later than 31st August } \\
2006 \\
\text { (Article } 3 \text { (1) Directive 2005/62/EC), } \\
\text { without prejudice of the transitional period } \\
\text { of } 9 \text { months of Article } 7 \text { of Directive } \\
\text { 2002/98/EC (Article } 3 \text { (1) of Directive } \\
\text { 2005/62/EC) }\end{array}$ \\
\hline
\end{tabular}

Products and Medical Devices and international experience in the concerned field have been taken into account to finally form the Directive 2002/98/EC of 27th January 2003 which also amends Directive 2001/83/EC.

Directive 2002/98/EC, which because of its central position in the regulation and implication system is here described as the 'mother directive' (fig. 1) is concerned with setting standards of quality and safety for the collection, testing, processing, storage and distribution of human blood and blood components. The first implementing Commission Directive 2004/33/EC of 22nd March 2004 [11] regards certain technical requirements for blood and blood components. The implementing Commission Directive 2005/61/EC of 30th September 2005 [12] contains traceability requirements and requirements for the notification of serious adverse reactions and events. Subject of the implementing Commission Directive 2005/62/EC of 30th September 2005 [13] are Community standards and specifications relating to a quality system for blood establishments. Detailed provisions are subject to the Directives' annexes (table 1).

\section{Overview of the Regulatory and Medical Implications of the European Blood Directive 2002/98/EC and the Implementing Commission Directives 2004/33/EC, 2005/61/EC and 2005/62/EC}

The European Blood Directive with the Commission Directives provide for the first time a mandatory regulatory basis for blood and blood component safety in Europe giving uni- 
Table 1. Survey of the structure of the Annexes to Directives 2002/98/EC, 2004/33/EC, 2005/61/EC and 2005/62/EC

\begin{tabular}{|c|c|c|}
\hline Annex & Title and basic content & Referring Article \\
\hline \multicolumn{3}{|c|}{ Directive 2002/98/EC } \\
\hline Annex I & $\begin{array}{l}\text { information to be provided by blood establishments to the competent authority for the purposes } \\
\text { of designation, authorization, accreditation or licensing }\end{array}$ & Article 5 (2) \\
\hline Annex II & report of the blood establishment's preceding year's activity & Article $13(1)$ \\
\hline Annex III & labeling requirements & Article 14 (1) \\
\hline Annex IV & basic testing requirements for whole blood and plasma donations & Article 13 (1) \\
\hline \multicolumn{3}{|c|}{ Directive 2004/33/EC } \\
\hline Annex I & definitions & Article 1 \\
\hline Annex II & information requirements & \\
\hline Part A & information to be provided to prospective donors of blood and blood components & Article 2 \\
\hline Part B & information to be obtained from donors by blood establishments at every donation & Article 3 \\
\hline Annex III & eligibility criteria for donors of whole blood and blood components & Article 4 \\
\hline Annex IV & storage, transport and distribution conditions for blood and blood components & Article 5 \\
\hline Annex V & quality and safety requirements for blood and blood components & Article 6 \\
\hline \multicolumn{3}{|c|}{ Directive 2005/61/EC } \\
\hline Annex I & record of data on traceability by blood establishments and by facilities & Article 4 \\
\hline Annex II & notification of serious adverse reactions & Article 5 (2) \\
\hline Part A & rapid notification format for suspected serious adverse reactions & \\
\hline Part B & serious adverse reactions - imputability levels & \\
\hline Part C & confirmation format for serious adverse reactions & \\
\hline Part D & annual notification format of serious adverse reactions & Article 5 (2) \\
\hline Annex III & notification for serious adverse events & Article 6 \\
\hline Part A & rapid notification format for serious adverse events & \\
\hline Part B & confirmation format for serious adverse events & \\
\hline Part C & annual notification format for serious adverse events & \\
\hline \multicolumn{3}{|c|}{ Directive 2005/62/EC } \\
\hline Annex & $\begin{array}{l}\text { quality system standards and specifications: (1) introduction and general principles, (2) personnel } \\
\text { and organization, (3) premises, (4) equipment and materials, (5) documentation, (6) blood collection, } \\
\text { testing and processing, (7) storage and distribution, (8) contract management, (9) non-conformance, } \\
\text { (10) self-inspection, audits and improvement }\end{array}$ & Article 2 (1) \\
\hline
\end{tabular}

form and comprehensive definitions and standards. Directive 2002/98/EC consists of 34 articles, divided up into 10 chapters providing general provisions (Articles 1-4), obligations of member state authorities (Articles 5-8), provisions for blood establishments (Articles 9-10), quality management (Articles 11-13), hemovigilance (Articles 14-15), provisions for the quality and safety of blood and blood components (Articles 16-23), data protection (Article 24), exchange of information, reports and penalties (Articles 25-27), committees (Articles 28-30) as well as final provisions (Articles 31-34).

In particular, Article 3 of the Directive 2002/98/EC, Article 1 and Annex I Directive 2004/33/EC, Article 1 Directive 2005/61/EC and Article 1 Directive 2005/62/EC each quote a catalogue of definitions for the main subjects of the Directives. Notably, these relevant terms have not previously been clearly defined or definitions have even been completely lacking in the national regulations in many of the member states. Since defined terms constitute the basis of uniformity, this setting of definitions is of the utmost importance to the harmonization of European blood and blood component comparability and transfer within Europe.

\section{Designation, Authorization, Accreditation or Licensing of Blood Establishments Including Inspection and Control Measures}

For the purpose of undertaking activities in connection with the collection and testing of human blood and blood components, irrespective of the intended purpose, and their preparation, storage and distribution when intended for transfusion, blood establishments require - pursuant to Articles 5 and Annex I Directive 2002/98/EC - designation, authorization, accreditation or licensing by the competent authority, which can also be conditional or restricted to certain activities and may even be suspended or revoked.

Following Articles 8 and 15 of Directive 2002/98/EC, inspection and control measures under the organization of the competent authority take place in blood establishments on a regular basis as well as on the occasion of serious adverse reactions or events or the suspension thereof. In this respect, inspecting and controlling officials are provided with adequate competence. 


\section{'Responsible Person' in Blood Establishments and Personnel in Blood Establishments and Hospital Blood Banks}

In Article 9 of the Directive 2002/98/EC, the European Blood Directive has introduced the term and function of a scientifically and practically qualified 'responsible person' in blood establishments, whose field of functions basically consists of ensuring compliance with the Directives and with national law. If directly involved in the collection, testing, processing, storage and distribution of human blood and blood components in blood establishments and hospital blood banks, personnel in general has to be qualified to perform these tasks and to be trained in a timely, relevant and regularly updated manner (Articles 10 and 6 Directive 2002/98/EC).

\section{Quality Management}

Directive 2002/98/EC considers as the mandatory elements of quality management a quality system based on the principles of good practice for blood establishments and hospital blood banks (Articles 11, 6 Directive 2002/98/EC, Directive 2005/ $62 / E C$ ), documentation on operational procedures, guidelines, training and reference manuals and reporting forms in blood establishments and hospital blood banks (Articles 12, 6 Directive 2002/98/EC) and record keeping for a minimum of 15 years concerning the following aspects: i) reporting of the activities of the blood establishment in the preceding year (Annex II Directive 2002/98/ EC), ii) basic testing requirements for whole blood and plasma donations (Annex IV Directive 2002/98/EC), iii) information to be provided to donors (Article 29 (b) Directive 2002/98/EC, Article 2, Annex II A Directive 2004/33/EC), vi) information required from donors (Article 29 (c) Directive 2002/98/EC, Article 3, Annex II B Directive 2004/33/EC), and v) eligibility of donors (Article 29 (c) Directive 2002/98/EC, Article 4, Annex III Directive 2004/33/EC) in blood establishments (Article 13 Directive 2002/98/EC). It is the Directive 2005/62/EC which - notably in its Articles 1 and 2 and in its Annex - contains the community standards and specifications relating to the quality system in blood establishments.

The standards and specifications of the Annex to Directive 2005/62/EC are partly presented in the form of general principles (Number 1 Annex to Directive 2005/62/EC) and partly they comprise an extensive collection of detailed and concrete requirements (Numbers 2-10 Annex to Directive 2005/62/ EC). However, some requirements leave the concrete realization to the member states, e.g. Number 7.2. Annex to Directive 2005/62/EC, which demands validation of the procedures for storage and distribution but does not determine which kind of evidence has to be provided exactly. The equivalent rather vague principle can be found in some other requirements, e.g. concerning laboratory testing (Number 6.3.1.
Annex to Directive 2005/62/EC: 'all laboratory testing procedures shall be validated before use'; Number 6.3.5. Annex to Directive 2005/62/EC: 'there shall be data confirming the suitability of any laboratory reagents'; Number 6.3.5. Annex to Directive 2005/62/EC: 'quality of the laboratory testing shall be regularly assessed') or labeling (Number 6.5. Annex to Directive 2005/62/EC: 'labeled with relevant information of their identity'; Number 6.6.2. Annex to Directive 2005/62/EC: 'safe and secure system to prevent $[. .$.$] from being released until all$ mandatory requirements [...] have been fulfilled').

\section{Hemovigilance}

The European Blood Directive 2002/98/EC introduces mandatory hemovigilance according to Articles 14/15 and 6, respectively, and according to Directive 2005/61/EC as a standardized surveillance system to be set up by all blood establishments including hospital blood banks. The 2 central components of hemovigilance encompass i) traceability (Article 14 Directive 2002/98/EC) and ii) notification of serious adverse events and reactions (Article 15 Directive 2002/98/EC) which are subject to Directive 2005/61/EC.

'Traceability' - in terms of the possibility to trace each individual unit of blood or blood components derived thereof from the donor to its final destination and vice versa - has to be ensured through accurate identification procedures (Article 14 (4) Directive 2002/98/EC), record maintenance (Article 14 (3) Directive 2002/98/EC, Articles 2 (4), 4 Directive 2005/61/EC) and an appropriate labeling system facilitating comparability and promoting safe exchange of blood products within Europe (Article 14 (2), Annex III Directive 2002/98/EC). Of fundamental importance is, that all facilities must have a system in place to record each blood unit or blood component received, whether or not locally processed, and the final destination of that received unit, whether transfused, discarded or returned to the distributing blood establishment (Article 2 (4) Directive 2005/61/EC).

Remarkably, the European Blood Directive does not provide any detailed requirements for identification procedures. Instead, the Directive marks identification points in the blood transfusion chain which have to be ensured: blood establishments must be able to explicitly identify each donor, each blood unit collected and each blood component prepared, whatever its intended purpose, including the facilities to which a given blood component has been delivered (Article 2 (3) Directive 2005/61/EC).

It has to be annotated that Article 14 of the Directive 2002/98/EC and Articles 2-4 of the Directive 2005/61/EC concerning traceability lack clear conformity, since deviating or non-distinctive definitions and references of terms are used, and a non-homogeneous structure of the subdivisions is employed. Notably, the ambiguous references regarding hospital blood banks in Article 6 of the Directive 2002/98/EC applying 
to Article 14 of the Directive 2002/98/EC and consecutively to Article 4 of the Directive 2005/61/EC and Annex I to the Directive 2005/61/EC leave open whether 'hospital blood banks' have to be related to 'blood establishments' or to 'facilities'. The definitions for 'facilities' in Article 1 (f) of the Directive 2005/61/EC and for 'hospital blood banks' in Article 3 (f) of the Directive 2002/98/EC ('a hospital which stores and distributes and may perform compatibility tests on blood and blood components exclusively for use within hospital facilities, including hospital-based transfusion activities') are incongruent. However, logical aspects allow the assignment of 'hospital blood banks' to 'blood establishments' in the terms of the Directive 2005/61/EC. Still, the Directives' wording does not expressively mention this aspect.

\section{Notification of Serious Adverse Events and Reactions}

Article 15 Directive 2002/98/EC, Articles 5, 6, 8 and 9, Annex II Part A and Part C Directive 2005/61/EC encompass the 2 principal elements: i) as soon as known notification using the notification formats in Annexes II and III to Directive 2005/61/EC to the competent authority which is designated by the member state, and ii) establishment of a procedure accurate, efficient and verifiable to withdraw from distribution blood or blood components associated with this notification in blood establishments and hospital blood banks. Regarding content and conception, these prescriptions are of a strict character not allowing implementation latitude to the member states. Remarkably, the term 'as soon as known' requires immediate action from the moment of disclosure. However, legally, 'known' only covers positive knowledge in the meaning of intention and not expressively 'could have known' in the meaning of negligence.

\section{Provisions for the Quality and Safety of Blood and Blood Components Including the Prevention of the Transmission of Viruses, Bacteria and Parasites}

The structure of the Directives' provisions for the quality and safety of blood and blood components consists of i) donor-related provisions (Articles 16-19 Directive 2002/98/EC) which include eligibility of donors (Article 18 Directive 2002/98/EC, Article 4, Annex III Directive 2004/33/EC), the requirement of information from donors (Article 17 Directive 2002/98/EC, Article 3, Annex II B Directive 2004/33/EC), the examination of donors (Article 19 Directive 2002/98/EC) and the provision of information to prospective donors (Article 16 Directive 2002/98/EC, Article 2, Annex II A Directive 2005/62/EC), ii) provisions on voluntary and unpaid blood donation (Article 20 Directive 2002/98/EC), iii) testing of donations (Article 21, Annex IV Directive 2002/98/EC), iv) storage, transport and distribution conditions (Article 22 Directive 2002/98/EC, Arti- cle 5, Annex IV Directive 2004/33/EC), v) quality and safety requirements for blood and blood components (Article $23 \mathrm{Di}$ rective 2002/98/EC, Article 6, Annex V Directive 2004/33/EC) and vi) autologous donations (Article 7 Directive 2004/ 33/EC).

For the first time, a European Directive declares the preferential encouragement of volunteer and unpaid donation as far as possible and allots regular control documents regarding measures undertaken to encourage volunteer donations (Article 20 Directive 2002/98/EC). The terms 'encourage' and 'as far as possible' leave a certain scope to the member states. Apparently being aware of this fact, the Community demands the submission of reports concerning the measures taken in order to encourage voluntary and unpaid donations to the Commission by the member states 2 years after the Directive 2002/98/ EC became effective, and thereafter every 3 years. On the basis of these reports, the Commission shall inform the European Parliament and the Council of any necessary further measures it intends to take at Community level.

Obligatory testing for whole blood and apheresis donations, including autologous predeposit donations, for the following parameters is specified in Article 21 and Annex IV of the Directive 2002/98/EC and implies the testing of i) ABO group (not required for plasma intended only for fractionation), ii) $\mathrm{RhD}$ group (not required for plasma intended only for fractionation), and iii) the following infections in the donors: hepatitis $\mathrm{B}$ (HBsAg), hepatitis $\mathrm{C}$ (anti-HCV), human immunodeficiency virus $1 / 2$ (anti-HIV 1/2). However, the Directive explicitly permits the member states to set requirements for additional tests for specific components or donors or epidemiological situations (Annex IV of the Directive 2002/98/EC). Thus, it is important to note that the European Blood Directive includes only a subset of serological safety tests and does neither demand for NAT (nucleic acid amplification) testing for HIV1/2, HCV or HBV nor requires serologic testing of anti-HBc antibody, Treponema pallidum antibodies, nor an indirect Coombs test in donations, whereas for example the German system provides NAT testing for HCV and HIV, testing for T. pallidum antibodies and an indirect Coombs test (§§ 5 III, 12 I 1 Transfusionsgesetz, Numbers 2.2.1 and 2.4.1 Guidelines for Hemotherapy of the Bundesärztekammer). Besides, the recommendations in Annex III Directive 2004/33/EC regarding the admission criteria for donors lack explicit exclusion criteria for several relevant parasitic infectious diseases, e.g. mucocutaneous leishmaniosis or trypanosomiasis, while other guidelines regarding for instance toxoplasmosis, do only apply to blood but not to plasma designed for fractionation. In view of the occurrence of some of these infectious diseases in certain European countries, the continuous presence of immigrants from endemic countries, and the extent of international travel, these risks may not have received sufficient attention [14]. Another possible gap in quality homogeneity pertains to the non-adherence to the In Vitro Diagnostic Medical Devices Act (IVDD 98/79/EC) which re- 
quires CE-marked reagents and tests to be used throughout Europe operative since December 2003 [15]. However, for several transfusion-transmissible parasitic diseases only heterogeneous 'in-house' tests are available. Together, these aspects illustrate present gaps in the European Blood Directive, precluding an entirely uniform exertion. Furthermore, Annex IV to Directive 2004/33/EC sets decided demands concerning storage conditions and duration for both liquid storage and cryopreservation.

Annex V.1 to Directive 2004/33/EC specifies those blood components which may be further processed within blood establishments and must be labeled accordingly. The distinct quality control requirements for these components are listed in Annex V.2 to Directive 2004/33/EC. For new blood components, quality and safety requirements must be regulated by the competent national authority, and such new components must be reported to the European Commission allowing future Community actions.

In Annex V.2.2 to Directive 2004/33/EC, it is required that appropriate bacteriological control of the collection and manufacturing process must be performed. Although this requirement is placed inconspicuously in Annex V.2.2 to Directive 2004/33/EC and does not further specify the meaning of 'appropriate' and 'bacteriological', it employs the term 'must be' which in the wordings of the Directives is rather seldom. Thus, the interpretation that performing bacteriological control is absolutely obligatory to the member states is unambiguous. Nevertheless, it is again left open to the member states to decide the exact implications of 'appropriate' and 'bacteriological control'. Here, the Directive leaves open whether testing of a certain proportion of non-transfused blood products as is performed in many member states as quality control measure (e.g. Germany) has to be performed, or whether all blood products will be subject to bacteriologic testing and control before transfusion to the patient. In any case, this passage contains a requirement which until now has basically not been fulfilled by most of the member states and could be of immense practical impact regarding bacterial testing implementations, production efforts and costs.

\section{Requirements for Imported Blood and Blood Components from Third Countries}

According to Article 2 (3) of Directive 2005/62/EC, Article 7 of Directive 2005/61/EC and Annex V.2.3. to Directive 2004/33/EC, in the stages preceding importation, a quality system for blood and blood components, a system of traceability and notification, and equally standards of quality and safety for blood and blood components imported from third countries and intended for use or distribution in the Community must exist, each of these being equivalent to the Directives' requirements.

Again, the requirement of equivalence leaves a wide interpre- tation range to the member states, since the content is rather vague. In particular, the formulations 'equivalent level of traceability' and 'quality system (...) equivalent to the (EU's) quality system' implicate that level and systems in third countries need not to consist of conception and elements identical with the EU prescriptions but must in sum guarantee not less safety than the EU does. The EU Directives do not contain any evaluation of traceability and quality systems in third countries (e.g. U.S.A.), neither are any guidelines provided, granting orientation to the member states about how traceability and quality systems in third countries could be uniformly evaluated. Hence, in the absence of consistent criteria, the safety regarding blood and blood components imported from third countries does not meet the same uniformity as guaranteed by the member states.

\section{Data Protection and Confidentiality}

Pursuant to Article 24 Directive 2002/98/EC, all collected data - including genetic information - to which third parties have access shall be rendered anonymous by using data security measures and safeguards against unauthorized data interaction and procedures to resolve data discrepancies and to prevent information from being disclosed in an unauthorized way, so that the donor can no longer be identified, but still guaranteeing the traceability of donations.

\section{Harmonizing Success of the European Blood Directive}

The Directive's success relies on the wide and uniform distribution of its regulations and on the existence of efficient sanctions in case of a behavior which is incongruent to the Directive's requirements. The Directives' main aspects are i) designation, authorization, accreditation or licensing of blood establishments and hospital blood banks depending on the national authorities' (represented by their officials) consent based on submitted information, inspection and control measures, ii) presence of a qualified responsible person and personnel in blood establishments and hospital blood banks, iii) a quality system for blood establishments and hospital blood banks based on the principles of good practice including documentation, guidelines, training, reference manuals and record keeping of a) data on labeling requirements, basic testing requirements, information required from donors, information provided to donors and eligibility of donors for at least 15 years, and b) data on traceability for at least 30 years, iv) hemovigilance obtained through traceability consisting of a) identification and verification procedures, record maintenance, labeling system, tracing of blood components to their location and processing stage in blood establishments, recording of each blood unit or blood component received and of its final destination in facilities, and b) notification of serious adverse events and reactions 
to the competent authority as well as withdrawal from distribution of such blood or blood components associated with a notification, v) quality and safety requirements of blood and blood components, such as a) donor eligibility, donor information and donor examination, b) voluntary and unpaid blood donations, $\mathrm{c}$ ) testing of whole blood and apheresis donations (ABO group, RhD group, HBsAg, anti-HCV, anti-HIV 1/2), d) storage, transport and distribution conditions and e) bacteriological control, vi) equivalent levels of quality systems, traceability and notification as well as of standards of quality and safety in third countries from which blood and blood components are imported, and finally vii) rendering anonymous all data to which third parties have access so that the donor can no longer be identified.

In this respect, the Directives' requirements follow the blood product production and utilization chain starting at the collection then testing, processing and storage, until the distribution of blood and blood components. The organization of health services and the provision of medical care expressively remains within the responsibility of each member state (Reasons (33) Directive 2002/98/EC). These 2 responsibilities do not affect the blood transfusion chain itself. Thus, they do not interfere with the fact that the regulation complex around the European Blood Directive covers the entire blood transfusion chain. This materially complete coverage is of essential importance for an effective harmonization, the intention thereof being a high level of health protection.

For sanctions in the case of member state nonconformance, the distinction between the implementation level and the application level has to be considered. If a member state infringes its obligation to implement the European Blood Directive and its performing Commission Directives according to Articles 249 (3) and 10 EC Treaty and individual interests are cumulatively breached, the institute of state liability [16] can award damages to injured individuals. Amongst others, this requires a qualified - in other terms an obvious and relevant - infringement, such as complete nonimplementation or faulty and delayed implementation. Besides, a direct causal connection between the infringement and the injury to the individual has to be shown. In practice, this means that an individual injured by blood and blood component safety-related events due to an infringement of the implementation obligation may obtain his or her damages from the member state.

At the application level, penalties based on national rules and for the first time due to EU intervention - according to Article 27 of the Directive 2002/98/EC as well as national liability rules in the case of damage have to be considered. The European Blood Directive itself obliges the member states to rule and implement effective, proportionate and dissuasive penalties applicable to infringements of the national provisions adopted pursuant to the Directive. Leaving concrete conception - e.g. of national responsibilities - to the member states, the Community controls the implementation of penalties by the member states' duty to have reported the provi- sions related to the penalties to the Commission at the latest by 8 th February 2005 and to have notified them without delay of any subsequent amendments affecting them. This kind of strict control is an innovation and has to be considered as an effective way to promote the realization of the Directive's requirements. It is therefore a valuable contribution to harmonization success. Of course, any health care professional and institution or the state itself can be liable according to the national law (in Germany according to Paragraphs 280 or 823 or 839 of the Bürgerliches Gesetzbuch) in the case of harm caused to an individual due to nonconformance and faulty acting. In conclusion, the European Blood Directive disposes of extensive complexity as well as effective sanctions enabling and guaranteeing its success in practice.

\section{Outlook Considering Selected Implementing Reactions in the Member States}

The success of harmonization obviously depends on the national implementation by the member states. Implementation costs have so far not been subject to any concrete financial calculation. Nevertheless, Faber [1] presents an estimation based on the different quantity of implementing investments in the member states, particularly taking into account the 10 acceding countries, which establishes an order of magnitude of billions of Euros. Irrespective of these expected costs, implementation activities can be observed. This is primarily the case in the 3 countries which represent the 3 historically different legal systems existing in Europe. These countries are Germany (German legal system), France (Romanic legal system) and the United Kingdom (Common Law).

In Germany, the transfusion law 'Transfusionsgesetz' (TFG), the 'Guidelines for Hemotherapy of the Bundesärztekammer' as well as the 'Arzneimittelgesetz' (AMG) and the 'Betriebsverordnung für pharmazeutische Unternehmer' (Pharm BetrV) had already been implemented in the late 1990s. The existence of the European Blood Directive resulted in the first novel of the TFG [17] and in amendments of the AMG and the PharmBetrV [18] and of the Guidelines for Hemotherapy of the Bundesärztekammer [19]. In certain points, the European Blood Directive even upgraded the - at that time already rather advanced - national standards. In particular, unpaid blood donations were emphasized ( $\$ 1$ TFG), and the term 'blood donation' was redefined according to the uniform European definition ( $\$ 2 \mathrm{TFG}$ ). The presence of an approbated medical person during blood donations and the inauguration of a medical management of blood establishments ( $\S 4$ TFG) were required. This last requirement is in fact exceeding the EU Directive which does not formally require medical doctors but allow formal qualifications in the field of biological sciences. Furthermore, a new register for transplantation of stem cells was established ( $\$ 9$ TFG). The obligations of maintaining a quality management system including labeling 
Table 2. Comparison of the information to be submitted by blood establishments to the competent authority pursuant to Article 5 Directive 2002/98/EC and the Blood Safety and Quality Regulations 2005

Annex I Directive 2002/98/EGＢ？ Blood Safety and Quality Regulations 2005 Regulations 4 (3), (4) and 3 (2)

Identification of the blood establishment

Name, qualification and contact details of responsible persons

List of hospital blood banks which it supplies

Description of the quality system, to include:

- Documentation, such as an organization chart, including responsibilities of the responsible persons and reporting relationships,

- Documentation, such as a site master file or quality manuals describing the quality system in accordance with Article 11 (1)

- Number and qualifications of personnel

- Hygiene provisions

- Premises and equipment

- List if standard operating procedures for recruitment, retention and assessment of donors, processing and testing, distribution and recall of blood and blood components and reporting and recording ofserious adverse reactions and events
Name and address of the blood establishment and general information about its activities which shall include

i) details of each site at which it wishes to carry out any of the activities referred to in regulation 3 (2),

ii) description of the activities which it wishes to carry out at each site,

iii) where it has or intends to enter into a contractual arrangement with any person to carry out any of the services in respect of which it is seeking authorization, the name and address of that person and of the services which he will carry out,

iv) name, qualifications and contact details of the responsible person for the establishment,

v) list of hospital blood banks which it supplies; and

Description of the quality system in place at each site for each activity in respect of which the application for authorization is made, which shall include the following information:

i) documentation, such as an organization chart, setting out the responsibilities of the responsible persons and reporting relationships,

ii) documentation, such as a site master file or quality manual, describing the quality system and explaining how it meets the requirements of part 5 of the schedule,

iii) details of the number and qualifications of personnel

iv) details of hygiene provisions,

v) details of premises and equipment, and

vi) list of standard operating procedures for:

(aa) recruitment, retention and assessment of donors,

(bb) processing, testing, distribution and recall of blood and blood components, and

(cc) the reporting and recording of serious adverse reactions and events of containers, storage, control and traceability $(\S 11 \mathrm{a}$ TFG, $\S \S$ 1a (1), 8, 15 PharmBetrV), as well as the obligations on documentation ( $\S 11,14,15 \mathrm{TFG})$ and notification ( $\$ 21 \mathrm{TFG})$ were reinforced [20]. The German national requirements do not illustrate a homogeneous implementation of the EU specifications. The Directives' requirements are inserted in the already existing national blood transfusion system and its specifications. This circumvents the adoption of the Directives' conception and causes discrepancies, such as different deferral criteria for donors of blood and blood components (Annex III.2 Directive 2004/33/EC, Number 2.2 Guidelines for Hemotherapy of the Bundesärztekammer). Germany applies the EU criteria in a different structure as well as in a more detailed way (e.g. concerning persons with risk of infections transmissible by blood transfusion, transmissible spongiforme encephalopathies, drug abuse, malaria) and even operates criteria which are not mentioned by the Directives (e.g. allergies, clinical symptoms after vaccinations, pregnancy, breastfeeding, abortion, alcoholism). As exemplified for the German deferral criteria regarding the wording and the tech- nical point of view, it will be difficult to establish comparability of European Community and national written standards. In France, the 'Code de la santé publique', which is a collection of public health legislation, includes in the 20th edition of 2006 in its first part, book II (Articles L. 1211-1 to R. 1224-5, especially title II 'sang humain') the central implementations of the European Blood Directive which are in some matters even substantiated. For example, the principle of voluntary and unpaid blood donation is reflected in Article L. 1221-1, and simultaneously the aspect of anonymity of the blood donation itself is focused on. Like in Germany, the EU Directives are integrated in a preexisting national blood transfusion system. Consequently, the French legislative structure and its particular contents are - though incorporating the EU standards and specifications - not identical to the EU ones and comparability between EU and national law is aggravated. Until 2004, the United Kingdom had no specific law regarding blood transfusion [21], but rapidly transposed the Directives 2002/98/EC and 2004/33/EC into national law through the Blood Safety and Quality Regulations 2005 [22]. The law 
came into force on 8th February 2005 in conformity with Directive 2002/98/EC and had to be implemented by 8 th November 2005, while an amendment to the regulations came into force on 8th April 2005. In all, the Blood Safety and Quality regulations 2005 represent a complete and largely literal implementation of the EU requirements into the national transfusion system. Moreover, the Blood Safety and Quality Regulations also contain a very detailed, extensive concretion of the European standards, which is highlighted in table 2.

Even in countries which had already implemented standards corresponding to those required in the European Blood Directive, significant differences in quality processes exist, namely in terms of definitions, organizational models, and particularly the status of implementation and development of hemovigilance [1, 23, 24]. In European countries which are in the process of implementation of comprehensive quality assurance systems in transfusion [25, 26], differences are obvious and pose a financial burden for each country, warranting a coordination of the national systems.

At present, the European Blood Directive has already contributed to unify standards for blood and blood components in Europe. It is to be noted that the cited national rules do not include the last Directives 2005/61/EC and 2005/62/EC but refer only to the Directives 2002/98/EC and 2004/33/EC. Allowing for the fact that the Directives 2005/61/EC and 2005/62/EC have to be implemented no later than 31st August 2006 (fig. 1) this situation demonstrates that the implementation process in the member states and hence the improvement of quality and safety standards evolve in a continuous process. The existence of continuous implication activities in the member states sets a positive signal promoting the process to a standardized and consistent frame for the rapidly developing field of transfusion medicine, which will allow the societies to benefit from a uniform level of blood safety all over Europe.

\section{References}

1 Faber JC: The European Blood Directive: a new era of blood regulation has begun. Transfusion Med 2004;14:257-73.

2 Watson R: EU tightens rules on blood safety. Brit Med J 2005;331:800.

3 Official Journal of the European Union L 311, 28.11.2001, p. 67.

4 Official Journal of the European Union C 164 30.6.1995, p. 1.

5 Official Journal of the European Union C 374 11.12.1996, p. 1

6 Official Journal of the European Union C 268, 4.10.1993, p. 29.

7 Official Journal of the European Union C 329, 6.12.1993, p. 268.

8 Official Journal of the European Union C 249, 25.9.1995, p. 231.

9 Official Journal of the European Union C 141, 13.5.1996, p. 131.

10 Official Journal of the European Union C 154 E, 29.5.2001, p. 141 and Official Journal of the European Union C 75 E, 26.3.2002, p. 104.
11 Official Journal of the European Union L 91, 30.3.2004, p. 25.

12 Official Journal of the European Union L 256, 1.10.2005, p. 32.

13 Official Journal of the European Union L 256, 1. 10. 2005 , p. 41

14 Garraud O: Post-transfusion parasite transmission: do the present controls fit with the EU directive? Transfusion Clin Biol 2005;12:275-85.

15 Dati F: The new European Directive on in vitro diagnostics. Clin Chem Lab Med 2003;10:1289-98.

16 Fundamental and exemplary: European Court of Justice of 5.3.96 C-46/93 and C-48/93, ECR 1996, I1029 (Factortame, Brasserie du pêcheur).

17 Bundesgesetzblatt Teil I, 18.2.2005, pp. 234-238.

18 Bundesgesetzblatt Teil I, 10.2.2005, pp. 234, 237.

19 Amendement of 19.9.2005, Bundesanzeiger of 5.11.2005.

20 Böck M: Novellierung des Transfusionsgesetzes: Konsequenzen für die praktische Arbeit. Bayerisches Ärzteblatt 2005;5:390-392.
21 Mascaretti L, James V, Barbara J, Cárdenas JM, Blagoevska M, Haračić M, Rossi U: Comparative analysis of national regulations concerning blood safety across Europe. Transfus Med 2004;14:105111

22 Blood Safety and Quality Regulations: Statutory Instrument 2005/50 and Statutory Instrument 2005/1098.

23 Faber JC: Worldwide overview of existing haemovigilance systems. Transfusion Apheresis Sci 2004 31:99-110.

24 Rouger P: Perspectives and organisation of haemovigilance in compliance with the European Directive 2002/98/EC. Transfusion Clin Biol 2004 11:119-22.

25 Goncalves MH, Muon MC, Goncalves JA: Transposition of the Blood Directive - perspective of Portugal. Transfusion Clin Biol 2005;12:18-20.

26 Potocnik M: Transfusional perspective in Slovenia. Transfusion Clin Biol 2005;12:21-24 